\title{
JEDNO SPECIFIČNO OGRANIČENJE PRAVA VLASNIŠTVA (PRENAMJENA POVRŠINE, UKLANJANJE ILI PRENAMJENA JAVNE ŠPORTSKE GRAĐEVINE)
}

\author{
UDK: $351: 347$ \\ Pregledni znanstveni rad \\ Primljeno: 1. IX. 2015.
}

U ovom tekstu autorica se bavi ograničenjem prava vlasništva kao dobro poznatim pravnim institutom, ali baš na konkretnom primjeru jednog posebnog ograničenja iz Zakona o sportu. Rado se o zabrani prenamjene površine, uklanjanju ili prenamjeni javne sportske građevine. Uz prikazivanje niza elemenata o ograničenjima uopće, $u$ tekstu je prikazala niz primjedbi na konkretno zakonsko rješenje, primjedbi koje praktično poništavaju inače dobru volju zakonodavca da i na ovaj način pomogne sportu.

Ključne riječi: pravo vlasništva, ograničenje, nekretnina, ustavnost

\section{UVOD}

Pravo vlasništva je temeljno pravo, ako ne prava općenito, tada svakako barem privatnog prava. Kako se često obvezno pravo naziva kraljicom prava, tako je barem jednako točno pravo vlasništva nazvati kraljem prava ili kraljevskim pravom. Otegotno je što su vlasničke teme toliko mnogo i kvalitetno obrađivane, od strane kako domaćih tako i stranih znanstvenika i stručnjaka uopće.

Baviti se danas ograničenjima prava vlasništva nema mnogo veze s istom tom temom ranije, ne samo u vrijeme rimskog prava, nego čak ni s tom istom temom prije samo nekoliko desetaka godina. Pravo je dio društvene stvarnosti i jednostavno ne može ne biti ograničeno tom istom stvarnošću. Naravno, taj utjecaj nije isti u različitim društvenim sustavima i vremenima, jedno su ograničenja svojstvena socijalizmu, tako vrlo naglašena u bivšoj državi (u svojoj osnovi to su ograničenja koja su negirala samu bit privatnog vlasništva), a potpuno nešto drugo su ograničenja svojstvena svakoj moderno uređenoj pravnoj državi koja su rezultat nužnih kompromisa odnosno koja su posljedica nesporne činjenice da je svako pravo vlasništva objektivno ograničeno drugim pravima vlasništva i šire gledano to u konačnici i nisu ograničenja, jer da ih nema, i to pravo vlasništva bi bilo uništeno drugim, također neograničenim, pravima vlasništva. ${ }^{1}$

1 Školski primjer nužnog ograničenja je (ne)primjena načela uti, frui, abuti na stan u sredini (ili bilo gdje osim eventualno na samom vrhu) nekog nebodera. Daje to pravo vlasništva na tom stanu neograničeno abusus bi značio pravo uništiti taj stan kao objekt prava vlasništva, ali to nikako nije moguće bez štete po druge objekte prava vlasništva u toj istoj zgradi, što znači i da je pravo uništenja tog stana nemoguće, drugim riječima da ne postoji. 
Predmet ovog teksta je jedno slabo poznato ${ }^{2}$ ograničenje prava vlasništva sadržano u Zakonu o sportu ${ }^{3} \mathrm{i}$ to u čl. 68. prema kojemu nije moguće prenamijeniti površinu planiranu za javnu športsku građevinu, ukloniti ili prenamijeniti javnu športsku građevinu za namjene koje nisu športske djelatnosti, osim u točno navedenim iznimnim situacijama. Prigodom tumačenja te zakonske odredbe nije dovoljno samo tumačiti riječi iz iste, nego je nužno dovesti to u svezu i s europskom pravnom stečevinom, kao i s Ustavom Republike Hrvatske. Europska pravna stečevina predstavlja pravni okvir svake domaće pravne norme zato što je Republika Hrvatska od 01. 07. 2013. punopravna članica EU, a Ustav Republike Hrvatske je najviši pravni akt s kojim svi zakoni moraju biti usklađeni, jer ako nisu, to usklađenje se provodi u propisanom ustavnosudskom postupku u kojemu se određeni zakon u cjelini ili u određenom dijelu ukida, što znači da te pravne norme više ne postoje. ${ }^{4}$ Povod su bila događanja u Osijeku gdje se danima u medijima prikazivala dvojba da li prenamijeniti sportsko igralište jednog od fakulteta u parkiralište, a da pri tome izgleda nitko ni jednom riječju nije ozbiljno ni spomenuo (kamo li uvažio) naprijed navedeno zakonsko ograničenje. Da stvar bude još gora, u konkretnom je slučaju Filozofski fakultet odlučio svoje sportsko igralište prenamijeniti u sklopu izgradnje buduće zgrade, a prosvjeduje obližnja osnovna škola koja preko 50 godina koristi to igralište bez ikakvog plaćanja i pri tome tom istom fakultetu naplaćuje korištenje svoje dvorane za tjelesni odgoj.

Analiza zakonskog rješenja kojim se bavimo u ovom tekstu ne uključuje samo utvrđivanje pravog značenja te pravne norme odnosno pravnih normi, nego uključuje i ocjenu je li to rješenje u skladu s Ustavom RH i europskom pravnom stečevinom, ali i ocjenu je li se ista svrha mogla postići kvalitetnijim zakonskim rješenjem i (za slučaj potvrdnog odgovora) kako bi to rješenje trebalo izgledati de lege lata.

2 Iako ne raspolažemo nekim znanstvenim istraživanjem koje bi to potvrdilo, ovo navodimo u smislu da se radi o nečemu što još nije doživjelo značajniju primjenu u praksi, pa ni kritiku neovisno o praksi. Ono što je čudno jest što se radi o rješenju ,starom“ gotovo 10 godina koje nije ni na koji način ,taknuto“ niti jednom od pet novela Zakona o sportu (kao ni u nacrtu Zakona o sportu koji se nalazi u zakonodavnoj proceduri i prošao je fazu tzv. savjetovanja sa zainteresiranom javnošću - vidjeti i Kodeks savjetovanja sa zainteresiranom javnošću u postupcima donošenja zakona, drugih propisa i akata - NN 140/09. - u daljnjem tekstu: Kodeks ili Kodeks savjetovanja sa zainteresiranom javnošću u postupcima donošenja zakona, drugih propisa i akata).

3 Zakon o sportu, 71/06, 124/10, 124/11, 86/12, 94/13, 85/15 - u daljnjem tekstu: ZOS ili Zakon o sportu. Napomena: u ovom tekstu smo se, birajući između riječi šport i sport odlučili za sport, sukladno noveli Zakona o sportu iz 2012. koja je promijenila i naziv zakona. Inače, još u osnovnom zakonskom tekstu iz 2006. god. je (neovisno o nazivu samog zakona koji je sadržavao riječ šport) bila propisana donekle ravnopravna uporaba oba naziva, odnosno čl. 99., st. 3. glasi: Nazivi, opći akti, dokumenti i druge isprave koji su utvrđeni, doneseni, odnosno izdani do stupanja na snagu ovoga Zakona, a sadrže riječ: »sport« nemaju obvezu mijenjati ju u riječ: »šport«.

4 Vidjeti više u: Ustavni zakon o Ustavnom sudu Republike Hrvatske (NN 99/99, 29/02, 49/02 pročišćeni test, u daljnjem tekstu: Ustavni zakon ili Ustavni zakon o Ustavnom sudu Republike Hrvatske). 


\section{PRAVNA VRELA}

U ovom slučaju prima facie izgleda da je jedino pravno vrelo Zakon o sportu. Međutim, naravno da to ipak nije tako. S obzirom na to da svi zakoni moraju biti usklađeni s Ustavom Republike Hrvatske, ${ }^{5}$ onda i Ustav dobiva to značenje pravnog vrela. Zakon o vlasništvu i drugim stvarnim pravima ${ }^{6}$ jest sedes materiae u odnosu na sva vlasnička pitanja, što postaje još važnije zato što Republika Hrvatska nema građanski zakonik, pa samim tim ni mjesta (odnosno zakonika) gdje bi se tražili odgovori u slučaju dvojbe i/ili posebno pravnih praznina. Ovako, taj tako važni dio uopće ne postoji ${ }^{7}$ pa se tumačenje mora svoditi na sami zakonski tekst, naravno, vodeći računa o Ustavu RH, ali i o europskoj pravnoj stečevini. Iako je točno da se Konvencija za zaštitu ljudskih prava i temeljnih sloboda ${ }^{8} \mathrm{~s}$ pripadajućim protokolima (od kojih svakako treba izdvojiti protokol broj 1, koji se bavi baš pravom vlasništva) ${ }^{9}$ ne bavi zaštitom prava ni države ni jedinica lokalne uprave i samouprave, ipak to ne može značiti da ne samo Konvencija, nego i sudska praksa na njoj utemeljena ne predstavlja pravni okvir (samim tim ni

5 Ustav Republike Hrvatske, NN 56/90, 135/97, 113/00, 28/01, 41/01 - pročišćeni tekst, 55/01, 76/10, 85/10 - pročišćeni tekst - u daljnjem tekstu: Ustav.

6 Zakon o vlasništvu i drugim stvarnim pravima: Na temelju svoje nadležnosti utvrđene člankom 62. Poslovnika Hrvatskoga sabora (»Narodne novine«, br. 81/13), Odbor za zakonodavstvo Hrvatskoga sabora na 123. sjednici održanoj 14. srpnja 2015. utvrdio je pročišćeni tekst Zakona o vlasništvu i drugim stvarnim pravima koji je objavljen u NN 81/15 - u daljnjem tekstu: ZV ili Zakon o vlasništvu ili Zakon o vlasništvu i drugim stvarnim pravima. Pročišćeni tekst Zakona o vlasništvu i drugim stvarnim pravima obuhvaća Zakon o vlasništvu i drugim stvarnim pravima (»Narodne novine«, br. 91/96), Zakon o izmjenama i dopunama Zakona o prodaji stanova na kojima postoji stanarsko pravo (»Narodne novine«, br. 68/98), Odluku Ustavnog suda Republike Hrvatske br. U-I-58/97, U-I-235/97,U-I-237/97, U-I-1053/97 i U-I-1054/97 od 17. studenoga 1999. (»Narodne novine«, br. 137/99), Odluku Ustavnog suda Republike Hrvatske br. U-I-1094/99 od 9. veljače 2000. (»Narodne novine«, br. 22/00), Zakon o dopuni Zakona o vlasništvu i drugim stvarnim pravima (»Narodne novine« br. 37/00), Zakon o izmjeni i dopuni Zakona o vlasništvu i drugim stvarnim pravima (»Narodne novine«, br. 114/01), Zakon o izmjenama i dopunama Zakona o vlasništvu i drugim stvarnim pravima (»Narodne novine«, br. 141/06), Zakon o izmjenama i dopunama Zakona o vlasništvu i drugim stvarnim pravima (»Narodne novine«, br. 146/08), Zakon o izmjenama Zakona o vlasništvu i drugim stvarnim pravima (»Narodne novine«, br. 38/09), Zakon o izmjeni i dopuni Zakona o vlasništvu i drugim stvarnim pravima (»Narodne novine«, br. 153/09), Zakon o izmjeni Zakona o vlasništvu i drugim stvarnim pravima (»Narodne novine«, br. 143/12) i Zakon o izmjeni Zakona o vlasništvu i drugim stvarnim pravima (»Narodne novine«, br. 152/14), u kojima je utvrđeno vrijeme njihova stupanja na snagu.

7 Jako je teško prihvatiti da je Republika Hrvatska u odnosu na pitanje građanskog zakonika (još jednom) odlučila ići potpuno drugim pravcem od velike većine drugih država. Naravno da je moguće da jednom bude donesen i Europski građanski zakonik, ali je isto tako moguće da to bude u dalekoj budućnosti ili nikada. Do tada bi sigurno bilo bolje imati vlastiti građanski zakonik nego gledati kako svoje građanske zakonike usvajaju (i samim time podižu razinu pravne sigurnosti i vladavine prava u svojoj državi) države kojima bi po svim objektivnim kriterijima mi trebali biti uzor na zakonodavnom planu, a ne da se događa obrnuto.

8 Konvencija za zaštitu ljudskih prava i temeljnih sloboda, NN - Međunarodni ugovori broj 18/97, 6/99 - pročišćeni tekst, 8/99 - ispravak, 14/02 i 1/06 - u daljnjem tekstu: Konvencija ili Konvencija za zaštitu ljudskih prava i temeljnih sloboda.

9 Vidjeti više u: Jasna Omejec, „Konvencija za zaštitu ljudskih prava i temeljnih sloboda u praksi Europskog suda za ljudska prava“" - STRASBOURŠKI ACQUIS, drugo i dopunjeno izdanje, Novi informator, Zagreb, 2014. (1552 stranice), recenzenti Arsen Bačić i Miomir Matulović. 
status pravnih vrela) unutar kojega se moraju kretati svi, pa tako i država i jedinice lokalne uprave i samouprave.

Ono što je važno jest naglasiti da sva ta pravna vrela podliježu postupku tumačenja, što znači da su ta pravila (a naročito ona koja se odnose na ciljno ili teleološko tumačenje) condicio sine qua non svakog popisa pravnih vrela. Načelno su pravna vrela i sudska praksa i pravna znanost (uključujući i stručne tekstove), ali da bi ta načelnost dosegla potrebnu razinu konkretnosti (u smislu uporabljivosti) bilo bi potrebno imati više od jednog ili nekoliko tekstova i više od jedne ili minimalnog broja sudskih odluka, uz poželjnu konfrontiranost stavova i argumentirane zaključke o tome koji stav i zašto treba podržati, a koji i zašto ne. Pri tome je jako značajno naglasiti da je po Ustavu najviši sud u Republici Hrvatskoj Vrhovni sud Republike Hrvatske koji ima pravo i obvezu ujednačavati sudsku praksu, a istodobno mu je to onemogućeno na najmanje dva načina ili iz najmanje dva razloga. Prvi je što veliki broj sudskih postupaka nema uvjeta za pristup revizijskom sudu (odnosno Vrhovnom sudu Republike Hrvatske) bilo zato što se radi o vrsti predmeta kod kojih je revizija isključena (ovršni, posjedovni...) bilo zato što se radi o predmetima kod kojih (bilo ab ovo, dakle do utuženja, bilo radi kasnijih promjena propisa za koje se smatra, jer se radi o pravilima postupka, da je prihvatljiv povratni učinak). ${ }^{10}$ Nažalost, izgleda da se na tu fazu treba još čekati. Kada se uzme u obzir notorna činjenica da se još uvijek čeka na donošenje niza podzakonskih akata propisanih Zakonom o sportu (a rokovi su već davno istekli, zakašnjenje se mjeri u godinama i vrlo je izvjesno da ćemo prije dobiti novi zakon nego podzakonske akte iz aktualnoga), onda to i nije toliko čudno, ali je u svakom slučaju loše obilježje postojeće situacije.

U nastavku smo citirali neke pravne norme koje su prema našem odabiru i koje, makar samo radi lakšeg praćenja teksta, imaju mjesta u ovom tekstu.

\section{USTAV}

\section{GOSPODARSKA, SOCIJALNA I KULTURNA PRAVA}

Članak 48.

\section{Jamči se pravo vlasništva.}

Vlasništvo obvezuje. Nositelji vlasničkog prava i njihovi korisnici dužni su pridonositi općem dobru.

Strana osoba može stjecati pravo vlasništva uz uvjete određene zakonom.

Jamči se pravo nasljeđivanja.

\section{Članak 49}

Poduzetnička i tržišna sloboda temelj su gospodarskog ustroja Republike Hrvatske.

10 Po našem mišljenju, kada se radi o vrijednosnom cenzusu za reviziju, to je apsolutno neprihvatljivo. 
Dr. sc. Blanka Ivančić-Kačer: Jedno specifično ograničenje prava vlasništva (prenamjena površine,... Zbornik radova Pravnog fakulteta u Splitu, god. 53, 1/2016., str. 299.-320.

Država osigurava svim poduzetnicima jednak pravni položaj na tržištu. Zabranjena je zlouporaba monopolskog položaja određenog zakonom.

Država potiče gospodarski napredak i socijalno blagostanje građana i brine se za gospodarski razvitak svih svojih krajeva.

Prava stečena ulaganjem kapitala ne mogu se umanjiti zakonom niti drugim pravnim aktom.

Inozemnom ulagaču jamči se slobodno iznošenje dobiti i uloženog kapitala.

\section{Članak 50.}

Zakonom je moguće u interesu Republike Hrvatske ograničiti ili oduzeti vlasništvo, uz naknadu tržišne vrijednosti.

Poduzetnička se sloboda $i$ vlasnička prava mogu iznimno ograničiti zakonom radi zaštite interesa i sigurnosti Republike Hrvatske, prirode, ljudskog okoliša i zdravlja ljudi.

\section{Članak 51.}

Svatko je dužan sudjelovati u podmirenju javnih troškova, u skladu sa svojim gospodarskim mogućnostima.

Porezni se sustav temelji na načelima jednakosti i pravednosti.

Članak 52.

More, morska obala i otoci, vode, zračni prostor, rudno blago i druga prirodna bogatstva, ali i zemljište, šume, biljni $i$ životinjski svijet, drugi dijelovi prirode, nekretnine $i$ stvari od osobitog kulturnoga, povijesnoga, gospodarskog i ekološkog značenja, za koje je zakonom određeno da su od interesa za Republiku Hrvatsku, imaju njezinu osobitu zaštitu.

Zakonom se određuje način na koji dobra od interesa za Republiku Hrvatsku mogu upotrebljavati $i$ iskorištavati ovlaštenici prava na njima $i$ vlasnici, te naknada za ograničenja kojima su podvrgnuti.

\section{ZAKON O SPORTU}

\section{OPĆA ODREDBA}

\section{Članak 1.}

(1) Ovim se Zakonom uređuju: sustav športa i športske djelatnosti, stručni poslovi u športu, športska natjecanja, financiranje športa, nadzor i ostala pitanja od značaja za šport.

(2) Šport se temelji na načelu dragovoljnosti.

(3) Šport mora biti jednako dostupan svima bez obzira na dob, rasu, spol, spolnu orijentaciju, vjeru, nacionalnost, društveni položaj, političko ili drugo uvjerenje.

(4) Športske djelatnosti utvrđene ovim Zakonom su djelatnosti od interesa za Republiku Hrvatsku.

(5) U Republici Hrvatskoj razvoj športa potiče se izgradnjom i održavanjem športskih građevina, školovanjem i usavršavanjem stručnog kadra, znanstvenim projektima u 
području športa, gospodarskim mjerama, stimuliranjem partnerstva vladinih i nevladinih organizacija u športu te privatnog poduzetništva i financiranjem športa sredstvima države, jedinica lokalne i područne (regionalne) samouprave i Grada Zagreba.

Novela zakona o sportu NN 86/12

\section{Članak 2.}

U članku 1. stavak 2. mijenja se i glasi:

»(2) Sportske djelatnosti su djelatnosti od posebnog interesa za Republiku Hrvatsku.«.

Stavak 4. briše se.

Dosadašnji stavak 5. postaje stavak 4.

\section{Članak 68.}

(1)Prenamijeniti površinu planiranu za javnu športsku građevinu, ukloniti ili prenamijeniti javnu športsku građevinu za namjene koje nisu športske djelatnosti može se samo uz suglasnost ministarstva na temelju prethodnog mišljenja športske zajednice na čijem se području nalazi športska građevina.

(2) Suglasnost iz stavka 1. ovoga članka ne može se izdati:

- ako jedinica lokalne, odnosno regionalne (područne) samouprave nije planirala odgovarajuću zamjensku površinu $i$

- ako investitori prenamjene javne športske građevine, odnosno vlasnik javne športske građevine koja se uklanja ne preuzme obvezu $\boldsymbol{i}$ osigura uvjete izgradnje odgovarajuće zamjenske javne športske građevine. (3) Iznimno od odredaba stavka 2. ovoga članka suglasnost se može dati samo ako se radi o građevini od posebnog interesa za Republiku Hrvatsku.

\section{KRATAK POVIJESNI PREGLED OGRANIČENJA PRAVA VLASNIŠTVA}

\section{III.1. OPĆENITO}

Točno je da se vrlo često pravo vlasništva smatra i definira kao jedino neograničeno stvarno pravo, ali činjenica je ne samo da ograničenja postoje danas, nego i da su postojala praktično oduvijek.

Da ne idemo dalje u prošlost, dovoljno je krenuti od vremena rimskog prava koje je bilo i ostalo temelj velikog dijela današnjeg pozitivnog prava u cijelom svijetu, a kada se ograničimo na Europu, onda je to značenje sigurno još i bitno veće. U vrijeme rimskog prava pravo vlasništva (rabio se pojam proprietas) ${ }^{11}$ definiralo se kao potpuna i isključiva pravna vlast na tjelesnoj stvari koju su svi drugi dužni poštovati, dok je Justinijan tu potpunost isticao kao plena in re potestas. Iako se sadržajno pravo vlasništva objašnjavalo poznatom trilogijom uti,

11 Proprietas,.tatis - f. - vlasništvo - prema: Hrvatsko-latinski enciklopedijski rječnik, Školska knjiga, Zagreb, 1997., str. 2863. 
frui, abuti, ipak je i tada bilo jasno da ograničenja postoje, kako ona utemeljena izravno na zakonu, tako i ona utemeljena na pravnom poslu, u svakom slučaju uz primjenu načela ius recadentiae ili načela elasticiteta prema kojemu se, kada ograničenje prestane, pravo vlasništva širi na onaj prvotni opseg ${ }^{12}$ (mi bismo dodali između riječi vlasništva i širi samo još i riječ automatski ili samo po sebi).

$\mathrm{Na}$ opisanom temelju razvijali su se moderni pravni poreci i nema ni jednog koji nije prihvatio nužnost ograničenja, što je nužnost koju gotovo da i ne treba objašnjavati. Da je drukčije, onda bi npr. etažni vlasnik nekog stana u smislu abususa imao pravo isti uništiti, što je nemoguće bez štete po druge etažne cjeline i što je zabranjeno zato jer je zabranjeno drugome nanositi štetu. Druga je stvar mjera u propisivanju zakonskih ograničenja, tu se relativno lako može pretjerati (bilo da je ograničenja previše, bilo da ih je premalo), a ako se pretjera, situacija može biti jednako loša ili možda i gora nego da ograničenja uopće nema. U jednom poznatom međunarodnom aktu (Deklaracija o pravima čovjeka i građanina iz 1789.) definiralo se pravo vlasništva polazeći do toga da to nije subjektivno pravo s točno unaprijed određenim sadržajem koje bi svojem nositelju davalo neke točno navedene ovlasti, nego je vlasnik ovlašten ,„činiti što ga je volja“ sa svojom stvari i koristima do nje (dakako s ogradom, ako to nije protivno tuđim pravima ni zakonskim ograničenjima“, a kasnije je upravo to pretočeno u većinu građanskih zakona tadašnje Europe, npr. Code civil (\& 544 - La propriete est le droit de joir et de disposer des choses de la maniere la plus absolue), ABGB (Allgemeines Burgerliches Gesetzbuch od 01. 06. 1811. - \& 354 - Als ein Recht betrachtet, ist Eigentum das Befugnis, mit der Substanz und den Nutzungen einer sache nach Willkur zu schalten, und jeden anderen davon auszuschliesen), \& 641 ZGB). ${ }^{13}$

\section{III.2. U BIVŠOJ DRŽAVI}

U bivšoj državi je od 01. rujna 1980. god. bio na snazi Zakon o osnovnim vlasničkopravnim odnosima ${ }^{14}$ koji je kasnije preuzet od strane Republike Hrvatske. ZOVO je sadržavao članak 3. koji je glasio:

Vlasnik ima pravo posjedovati svoju stvar, koristiti se i raspolagati njome $u$ granicama određenim zakonom.

Svatko je dužan suzdržavati se od povrede prava vlasništva druge osobe.

Pored ovog općeg ograničenja u nizu drugih zakona koji su imali položaj lex specialis postojala su i brojna posebna ograničenja. ${ }^{15}$

12 Marijan Horvat, Rimsko pravo, Pravni fakultet Sveučilišta u Zagrebu, 1998., str. 120.

13 Nikola Gavella, Tatjana Josipović, Igor Gliha, Vlado Belaj, Zlatan Stipković, Stvarno pravo, svezak 1., Narodne novine, Zagreb, 2007., str. 374.

14 Zakon o osnovnim vlasničkopravnim odnosima, SL SFRJ 6/80, 36/90 - u daljnjem tekstu: ZOVO.

15 Vidjeti vrlo opsežan popis u: Mladen Žuvela, Zakon o osnovnim vlasničkopravnim odnosima, komentar, sudska praksa i drugi odgovarajući propisi, Narodne novine, Zagreb, 1990., str. 24-26. 


\section{III.3. U REPUBLICI HRVATSKOJ}

Prigodom osamostaljenja Republika Hrvatska je, između brojnih drugih zakona, preuzela i ZOVO. ${ }^{16} \mathrm{U}$ stručnim krugovima taj zakon nikada nije dobivao visoku ocjenu, makar treba priznati i barem jedno objektivno objašnjenje za, s obzirom na to o kakvom zakonu se radi, stvarno nevjerojatno mali opseg i izostanak (osim iznimno $)^{17}$ detaljiziranja koje je kod instituta stvarnog prava u pravilu potrebno. To objašnjenje se svodi na to da je ZOVO bio zamišljen kao savezni zakon i u skladu s tadašnjom podjelom nadležnosti između federacija i njezinih 8 sastavnica (od koji je jedna bila tadašnja SR Hrvatska), upravo su sastavnice trebale donijeti svoje zakone koji se ne bi bavili ovim osnovama. U skladu sa svojim tadašnjim stavovima, tadašnja SR Hrvatska nikada nije donijela svoj zakon, a na njemu nažalost nije ni radila. ${ }^{18}$

Na dan 01. 01. 1997. na snagu je nakon dugog iščekivanja stupio Zakon o vlasništvu i drugim stvarnim pravima i u tom trenutku (u formalnom smislu, ali i bitno prije stupanja na snagu, posebno i za vrijeme javne rasprave, pojedina su rješenja praktično dobila ,pravo građanstva“, što je i više nego logično jer je taj zakon ispunio mnoge pravne praznine) dobili smo potpuno, kvalitetno i moderno rješenje kako instituta prava vlasništva uopće, tako i posebno ograničenja prava vlasništva. Iako opseg u smislu broja članaka i/ili stavaka i/ili riječi nije sam po sebi jamstvo za bilo što, pa tako ni za kvalitetu, ipak kada jedan zakon od 90 članaka (koliko ima ZOVO) bude zamijenjen sa 396 članaka (koliko je imao ZV u osnovnom tekstu), i to nešto znači. Međutim, kada se analiziraju oba zakona i unutar njih baš ograničenje prava vlasništva, razvidno je da su rješenja iz ZV-a i na tom planu bitno detaljnija i bitno bolja. Dosta je čudno što je primjer iz Republike Slovenije (Stvarnopravni zakonik) ${ }^{19}$, iako pod značajnim utjecajem i austrijskog i njemačkog prava, ipak na neki način bliži onome što je imao ZOVO (ali bez olakotnih okolnosti s obzirom na podjelu nadležnosti između federacije i sastavnica) jer (od ukupno 276 članaka) ima samo dva članka koja se bave definicijom prava vlasništva (čl. 37) i ograničenjima prava vlasništva (čl. 38), pri čemu je Stvarnopravni zakonik na snazi od 01. 01. 2003. ${ }^{20}$

16 Zakon o preuzimanju Zakona o osnovnim vlasničkopravnim odnosima, NN 53/91.

17 Npr. detaljan je bio čl. 31, ali to je istodobno i članak koji je nakon osamostaljenja u primjeni preuzetog ZOVO-a prouzročio upravo katastrofalne posljedice zato jer nije imao dovoljnu ,širinu“ da predvidi $\mathrm{i}$ pravilno uredi bitno promijenjene odnose (mislimo na masovnu pojavu krađa automobila $\mathrm{i}$ prodaju tih automobila putem komisijskih prodavaonica). Poznato je da je tu „krizu“ konačno riješio Vrhovni sud RH svojom presudom koja je kasnije poslužila onima koji su izrađivali tekst Zakona o vlasništvu i drugim stvarnim pravima da potpuno drukčije urede stjecanje od nevlasnika (čl. 117. ZV-a).

18 Ovo ne čudi kada se zna da je SR Hrvatska jedina od 8 sastavnica koja nije donijela svoj zakon o nasljeđivanju nego je svojom pasivnošću postigla da se bivši savezni Zakon o nasljeđivanju iz 1955. god. preuzeo kao republički. Pri tome je samo sretna okolnost da je to bio dobar zakon, a nemamo razloga vjerovati da je to inače bio promišljen i dobar potez tadašnje vlasti.

19 Stvarnopravni zakonik Uradni list Republike Slovenije broj 87/2002.

20 Više: Miha Juhart, Andrej Berden, Tomaž Keresteš, Vesna Rijavec, Matjaž Tratnik, Ana Vlahek, Renato Vrenčur, Stvarnopravni zakonik (SPZ) s komentarjem, GV Založba, Ljubljana, 2004., str. 213-237. 
Sama definicija i ograničenja se u Zakonu o vlasništvu i drugim stvarnim pravima nalaze u čl. 30-34 koji glase:

\section{Članak 30.}

(1) Pravo vlasništva je stvarno pravo na određenoj stvari koje ovlašćuje svoga nositelja da s tom stvari i koristima od nje čini što ga je volja te da svakoga drugoga od toga isključi, ako to nije protivno tuđim pravima ni zakonskim ograničenjima.

(2) U granicama iz stavka 1. ovoga članka vlasnik ima, među ostalim, pravo posjedovanja, uporabe, korištenja i raspolaganja svojom stvari.

\section{Opća ograničenja}

\section{Članak 31.}

Vlasništvo obvezuje i vlasnik je dužan pridonositi općem dobru, pa je općenito prilikom izvršavanja svoga prava dužan postupati obzirno prema općim i tuđim interesima koji nisu protivni njegovu pravu, a osobito:

- vlasnik se, a ni itko drugi, ne smije služiti svojim pravom s jedinim ciljem da drugome šteti ili da ga smeta,

- vlasnik nije ovlašten zabraniti tuđi zahvat u svoju stvar kad je taj nužan radi otklanjanja štete koja nekome neposredno prijeti, a nerazmjerno je veća od one što iz toga zahvata proizlazi za vlasnika, nego je samo ovlašten potraživati naknadu za pretrpljenu štetu,

- vlasnik nekretnine nije ovlašten braniti tuđe zahvate poduzete na tolikoj visini ili dubini gdje on nema nikakva opravdanoga interesa da ih isključi.

\section{Posebna ograničenja}

\section{Članak 32.}

(1) Vlasnik stvari ne smije izvršavati svoje pravo vlasništva preko granica koje su svim vlasnicima takvih stvari postavljene na temelju ovoga ili posebnih zakona radi zaštite interesa i sigurnosti države, prirode, ljudskoga okoliša i zdravlja ljudi.

(2) Vlasnik neke od stvari koje su na temelju Ustava posebnim zakonom proglašene stvarima od interesa za Republiku, i za koje je propisan poseban način njihove uporabe i iskorištavanja od strane njihovih vlasnika i ovlaštenika drugih prava na njima, dužan je izvršavati svoje pravo vlasništva s time u skladu, ali mu pripada pravo na naknadu za ograničenja kojima je podvrgnut.

(3) Kad je radi zaštite interesa i sigurnosti države, prirode, spomenika kulture, ljudskoga okoliša ili zdravlja ljudi određeno da je vlasnik na temelju zakona dužan nešto poduzeti glede vlastite stvari, a njega se na to ne može prisiliti, općinski načelnik, gradonačelnik odnosno župan je ovlašten uspostaviti privremeno upravljanje tom stvarju (sekvestraciju) primjenjujući na odgovarajući način pravila o privremenom skrbništvu nad ostavinom za slučaj da su nasljednici nepoznati ili nepoznatoga boravišta, ako posebni zakon ne određuje što drugo. 
Odredbom članka 1. Zakona o izmjenama Zakona o vlasništvu i drugim stvarnim pravima (»Narodne novine«, br. 38/09), koji je stupio na snagu 15. travnja 2009., u stavku 3. izmijenjen je dio teksta.

(4) U izvršavanju privremenoga upravljanja, općinski načelnik, gradonačelnik odnosno župan može stvari dati u zakup.

Odredbom članka 1. Zakona o izmjenama Zakona o vlasništvu i drugim stvarnim pravima (»Narodne novine«, br. 38/09), koji je stupio na snagu 15. travnja 2009., u stavku 4. izmijenjen je dio teksta.

(5) Ugovor o zakupu sklapa se na određeno vrijeme.

(6) U slučaju iz stavka 4. ovoga članka zakupnina se može koristiti samo za održavanje stvari ili za ispunjenje druge obveze zbog koje je uspostavljeno privremeno upravljanje stvarju.

(7) Vlasnik ima pravo na vraćanje posjeda stvari i prije proteka roka iz ugovora, ako u cijelosti isplati uložena sredstva ili ispuni drugu obvezu zbog koje je uspostavljeno privremeno upravljanje stvarju.

\section{Naknada}

\section{Članak 33 .}

(1) Pravo vlasništva može u interesu Republike Hrvatske biti zakonom oduzeto (potpuno izvlaštenje) ili ograničeno osnivanjem za drugoga nekoga prava glede vlasnikove stvari (nepotpuno izvlaštenje), u kojem slučaju vlasnik ima pravo na naknadu prema propisima o izvlaštenju.

(2) Bude li zakonom nekoj vrsti stvari oduzeta sposobnost da bude objekt prava vlasništva, to za dotadašnje vlasnike takvih stvari proizvodi jednake pravne učinke kao da je glede tih stvari provedeno potpuno izvlaštenje.

(3) Ako je vlasnik glede neke svoje stvari podvrgnut ograničenjima radi zaštite interesa i sigurnosti Republike Hrvatske, prirode, ljudskoga okoliša ili zdravlja ljudi, koja od njega, ali ne i od svih ostalih vlasnika takvih stvari, zahtijevaju težu žrtvu, ili ga inače dovode u položaj nalik na onaj u kojem bi bio da je provedeno izvlaštenje - on ima pravo na naknadu kao za izvlaštenje.

(4) $\mathrm{Ne}$ bude li razlog radi kojega je bilo provedeno neko izvlaštenje ostvaren $u$ propisanom, odnosno razumnom roku, izvlaštenik ima pravo zahtijevati da se uspostavi prijašnje pravno i faktično stanje koliko je to najviše moguće, ali tada smije zadržati samo onoliko od primljene naknade koliko je na gubitku u odnosu na stanje kakvo bi prema redovitom tijeku stvari bilo bez izvlaštenja.

Ograničenja na temelju pravnoga posla

\section{Članak 34 .}

(1) Ako nije što drugo određeno, vlasnik može u svaku svrhu koja nije zabranjena svoje pravo ograničiti, uvjetovati ili oročiti, a može ga i opteretiti. 
(2) Odredi li vlasnik pravnim poslom zabranu otuđenja ili opterećenja svoje stvari, to ga obvezuje. Ta će zabrana djelovati i prema trećima, ako je osnovana u korist bračnoga druga, djeteta, roditelja, posvojenika ili posvojitelja, a i upisana je u zemljišnu knjigu, odnosno u javni upisnik bez čega se ne može steći stvar za koju je zabrana određena.

(3) Odredi li vlasnik pravnim poslom uvjet ili rok pravu vlasništva, to ga obvezuje. Ograničenje uvjetom ili rokom djelovat će i prema trećima, ako je upisano u zemljišnu knjigu, odnosno u takav javni upisnik bez čega se ne može steći stvar za koju je ograničenje određeno.

(4) Vlasnik čije će pravo vlasništva prestati ispunjenjem uvjeta ili istekom roka (prethodni vlasnik) dužan je postupati obzirno prema onome tko čeka da time postane vlasnikom (potonji vlasnik) te mu prenijeti vlasništvo pošto istekne rok ili se ispuni uvjet, pri čemu će se njihov međusobni odnos prosuđivati kao da je prethodni vlasnik bio plodouživatelj. Kad je vlasništvo uvjetovano ili oročeno djelovanjem prema trećima, tada samim ispunjenjem uvjeta, odnosno istekom roka ono pripada potonjem vlasniku, ako zakonom nije drukčije određeno, a pravna raspolaganja stvarju koja je bio poduzeo prethodni vlasnik gube učinak.

(5) Vlasnik koji je dobio ili je pridržao pravo vlasništva određene stvari radi osiguranja ispunjenja neke tražbine, obvezan je propustiti služiti se i raspolagati tom stvari osim za namirenje te tražbine, a ovlašten je, ne bude li mu tražbina o dospijeću ispunjena, namiriti je iz stvari u skladu s pravilima o namirivanju zalogom osiguranih tražbina izvansudskim putem. Ograničenje vlasništva radi osiguranja tražbine djelovat će i prema trećima ako je upisano u zemljišnu knjigu, odnosno u takav javni upisnik bez upisa u koji se ne može steći stvar za koju je ograničenje određeno.

(6) I kad djeluju i prema trećima, vlasnikova ograničenja, uvjetovanja, oročenja i opterećenja stvari ne utječu na tuđa prava koja već postoje na stvari, osim ako njihovi nositelji na to u pisanom obliku izričito pristanu, a ne utječu ni na prava koja bi u pravnom prometu stekli treći koji nisu znali niti su mogli znati za tu ograničenost, uvjetovanost, oročenost ili opterećenost.

Osobito o vlasništvu Republike Hrvatske i drugih osoba javnoga prava

\section{Članak 35.}

(1) Republika Hrvatska i druge pravne osobe javnoga prava koje su nositelji prava vlasništva imaju kao vlasnici u pravnim odnosima jednak položaj kao i privatni vlasnici, ako zakonom nije što drugo određeno.

(2) Stvarima u vlasništvu Republike Hrvatske raspolaže, upravlja i koristi se Vlada Republike Hrvatske ili od nje ovlašteno tijelo ako posebnim zakonom nije drukčije određeno. Ovlasti za raspolaganje, upravljanje i korištenje stvarima u vlasništvu jedinica lokalne i područne (regionalne) samouprave imaju tijela jedinica lokalne i područne (regionalne) samouprave određena propisom o ustrojstvu lokalne i područne (regionalne) samouprave, osim ako posebnim zakonom nije drukčije određeno.

Odredbom članka 1. Zakona o izmjenama i dopunama Zakona o vlasništvu i drugim stvarnim pravima (»Narodne novine«, br. 146/08), koja odredba je stupila na snagu 17. svibnja 2009. u članku 35. stavku 2. izmijenjena je 2. rečenica. 
(3) Namjenu stvari u vlasništvu Republike Hrvatske određuje zakon ili državno tijelo koje je za to nadležno na temelju zakona.

(4) Svatko ima pravo stvarima u vlasništvu Republike Hrvatske koje su namijenjene za uporabu svih (javna dobra u općoj uporabi) služiti se na način koji je radi ostvarenja te namjene odredilo tijelo ili ustanova kojoj su dane na upravljanje, odnosno tijelo nadležno za određivanje namjene, koje njima neposredno upravlja. Ako nije što posebno propisano zakonom, na javna dobra u općoj uporabi na odgovarajući se način primjenjuju pravila koja vrijede za opća dobra.

(5) Stvari u vlasništvu Republike Hrvatske koje su namijenjene neposrednom izvršavanju prava i dužnosti Republike Hrvatske, njezinih tijela i ustanova (javna dobra u javnoj uporabi) rabe u skladu $s$ tom namjenom ona tijela $i$ ustanove kojima ih je dalo na upravljanje tijelo nadležno za određivanje namjene, ako ih to tijelo nije zadržalo u svojoj neposrednoj uporabi.

(6) Pravo vlasništva na stvarima u vlasništvu Republike Hrvatske koje nisu namijenjene za opću ni za javnu uporabu izvršava tijelo nadležno za određivanje namjene, ako to nije povjerilo kojem drugom tijelu, ustanovi ili osobi, a čisti prihod od tih stvari prihod je državnoga proračuna.

(7) Tko god odlučuje o općim dobrima ili o stvarima u vlasništvu Republike Hrvatske, ili njima upravlja, dužan je postupati kao dobar domaćin i odgovara za to.

(8) Na pravo vlasništva jedinica lokalne samouprave i jedinica lokalne samouprave i uprave na odgovarajući će se način primjenjivati pravila o vlasništvu Republike Hrvatske, ako nije što drugo određeno zakonom, niti proizlazi iz naravi tih osoba. Isto vrijedi i za pravo vlasništva ustanova, te s njima izjednačenih pravnih osoba.

Već je i prima facie očito da je ZV vrlo ozbiljan zakonski projekt. To vrijedi za ZV kao cjelinu, ali u svakom slučaju i za materiju ograničenja prava vlasništva. Bitno je pri tome naglasiti da ZV ima ulogu lex generalis, a ukoliko se neko drugo ograničenje (pa i ono iz Zakona o sportu) nalazi u nekom drugom zakonu (ali ne i u podzakonskom aktu, ograničenja iz takvih akata moraju svoj temelj imati u pojedinom zakonskom tekstu; ako ga nemaju onda su izvjesno nezakoniti i prijeti im ukidanje od strane Visokog upravnog suda Republike Hrvatske kao nadležnog suda $)^{21}$ što se rješava primjenom pravila lex specialis derogat legi generali.

${ }^{21}$ Prethodno (prije nego što je raniji Upravni sud Republike Hrvatske postao Visoki upravni sud Republike Hrvatske, uz formiranje četiri upravna suda u Osijeku, Rijeci, Splitu i Zagrebu) to je bila nadležnost Ustavnog suda Republike Hrvatske. 


\section{OGRANIČENJE IZ ČL. 68. ZAKONA O SPORTU}

\section{1. UVOD}

Generalno gledano, pravna ocjena struke za zakone iz područja sporta od osamostaljenja Republike Hrvatske do danas (a isto ili slično vrijedi i za prethodno razdoblje) prilično je niska, ${ }^{22}$ potpuno nesrazmjerna kvaliteta hrvatskog sporta. Na žalost svih koji se bave sportom, ali i onih koji bi to tek mogli pro futuro, kao i svih kojima je do sporta stalo, pravni okvir je dosta loš i vrlo često se loše rješenje „popravlja“" još lošijim i tako redom. ${ }^{23}$ Pored biti problema, loša ocjena odnosi se na i na proceduralna pitanja, što je kulminiralo time što se u 2015. godini, u vrijeme kada je već postojao integralni tekst novog Zakona o sportu upućen u javnu raspravu, pokrenuo i dovršio postupak donošenja novele Zakona o sportu što je vrlo neuobičajeno. Takvo stanje pogoduje osipanju sportaša u najširem smislu tog pojma (koji uključuje i natjecatelje i rekreativce i trenere i funkcionare, ali i navijače i samo simpatizere) na način da je interes sve manji i čudo je što još uvijek imamo dobre sportske rezultate ${ }^{24} \mathrm{i}$ to ne samo u pojedinačnim natjecanjima ${ }^{25}$ (gdje sustav ipak nije na jednak način condicio sine qua non kao u onim ekipnim), nego i u onim ekipnim. ${ }^{26}$

Upravo u kontekstu naprijed navedenih obilježja treba promatrati i zakonsku odredbu kojom se posebno bavimo u ovom tekstu - čl. 68., st. 1.-3. Zakona o sportu.

Ako pođemo od polazne pretpostavke ili hipoteze prema kojoj je sport ne samo od posebnog interesa, nego se i sportske djelatnosti često odvijaju na vrlo atraktivnim lokacijama ${ }^{27}$ koje su stalna „meta“ raznim poduzetnicima i „poduzetnicima“" u sprezi sa tijelima vlasti na različitim razinama (a svakoj vlasti,

22 Vidjeti tekst na tu temu: Hrvoje Kačer, Ante Perkušić, Blanka Ivančić-Kačer, „Postoji li u Republici Hrvatskoj (kvalitetno) sportsko pravo“, Zbornik radova Pravnog fakulteta u Splitu, god. 49, 4/2012, str. 727-740.

23 Školski primjer vrlo čudnih ,popravljanja“ jest čl. 13. Zakona o sportu koji je izvorno bio dosta loš, a kasnijim promjenama je u nekim dijelovima popravljen, ali istodobno u nekim i doveden na rub apsurda. Vidjeti više o tome u: Hrvoje Kačer, Ante Perkušić, Blanka Ivančić-Kačer, ibidem, str. 735-738.

24 Taj fenomen nije samo hrvatski; nedavno se dogodilo da je juniorska košarkaška reprezentacija Bosne i Hercegovine osvojila zlatnu medalju na europskom prvenstvu, a pri tome je trebala biti diskvalificirana jer nacionalni savez nije platio kotizaciju za natjecanje (što je nakon početka natjecanja platila jedna anonimna tvrtka, a isto se dogodilo i s hotelskim troškovima).

25 Ne treba posebno objašnjenje uz imena kao što su Sandra Perković (disk), Blanka Vlašić (skok u vis), Marin Čilić (tenis pojedinačno), Ivan Dodig (tenis u parovima) itd.

26 U muškom rukometu, nogometu, vaterpolu, bili smo i ostali svjetski vrh, a koliko su kriteriji visoki pokazuje i to što su svi nezadovoljni ili barem potpuno indiferentni na rezultate kao što je plasman među 10 ili 16 najboljih država na svijetu, i to sve u situaciji gdje u bilo kojoj gospodarskoj grani (osim turizma) ne možemo ni blizu najboljih 50 ili 100 država, a a najbolje hrvatsko sveučilište je izvan popisa najboljih 300 svjetskih sveučilišta.

27 Takve su lokacije npr. stadion HNK Hajduk u centru grada na kojemu se nogomet igrao do preseljenja u Poljud cca dva kilometra dalje i na kojemu se od tada do danas igraju ragbi i baseball, a često „gostuju“ razni sajmovi i cirkusi, košarkaške dvorane Cibone i Zadra (mislimo na staru dvoranu u Jazinama) i dr. 
čak i zanemarujući neke nedopuštene motive, kronično nedostaju sredstva, a nova izgradnja uvijek znači i sredstva za lokalne proračune, svakako kroz PDV i onaj centralni proračun), postavlja se pitanje jesu li jedini relevantni kriteriji kojim bi se trebalo baviti kod eventualne prenamjene i zamjenske površine površina (u smislu kvadrata) i eventualno oprema ili ipak i drugi kriteriji kao npr. u prvom redu vrijednost površine na kojoj je ili planirana ili i izgrađena javna sportska građevina u usporedbi s tom drugom površinom. Drugim riječima, što je pravo značenje čitavog niza pojmova, odnosno zakonskih formulacija, od kojih izdvajamo pojam odgovarajuća zamjenska površina. S obzirom na mogućnosti promjene pravnog statusa javne sportske građevine u privatnu sportsku građevinu, potrebno je utvrditi koji su učinci eventualne takve promjene na navedeno zakonsko ograničenje, ali i što s onim sportskim sadržajima koji su planirani, eventualno i građeni s pretpostavkom bitno drukčijih demografskih kretanja nego što su ona aktualna.

Posebno želimo naglasiti veliko značenje postupka tumačenja, jer pri potpuno jednakom zakonskom tekstu, ovisno o tumačenju, možemo dobiti u bitnom različite rezultate. Svaka pravna norma predstavlja skup riječi koje imaju određeno značenje ili određena značenja koja treba utvrditi. Uslijed čitavog niza uzroka, tom sklopu riječi (znakova) je često dosta složeno dati pravo značenje i na tom zadatku se vidi vrsnoća onoga tko primjenjuje (tumači) pravnu normu. Postoje općeprihvaćena pravila tumačenja, u dosta velikoj mjeri je prihvaćen i njihov međusobni odnos, ali ipak u praksi dolazi do problema. To je svojstvo ne samo kontinentalnoeuropskog prava (kojem pripada i hrvatski pravni sustav) nego i precedentnog prava, što problem svakako čini još značajnijim. Iako je u određenoj mjeri tako bilo i ranije (posebno nakon osamostaljenja), nakon stjecanja članstva u EU više nema nikakve dvojbe - u prvom je planu ciljno ili teleološko tumačenje. Ciljna (teleološka) metoda tumačenja jest metoda kojom se ispituje uloga pravne norme u društvu i zaključuje da je njeno pravo značenje u određenom pravnom odnosu ono značenje koje najbolje izražava vladajuće društvene ciljeve. Upravo ciljna metoda smatra se odlučnom u svim onim slučajevima postojanja više mogućih (vjerojatnih) pravih značenja, pa njena uporaba mora otkriti ono (jedino) pravo značenje te pravne norme. Zbog toga je ciljno tumačenje najvažnije, odlučno i završno u postupku tumačenja (razumijevanja) pravnih normi, a sva druga pravila tumačenja njemu su podređena i njemu služe. ${ }^{28}$

\section{IV.2. ANALIZA DE LEGE LATA}

Potrebno je priznati odmah na početku da je pozitivno već i to što se ovakva odredba (koja objektivno štiti, odnosno pogoduje sportu) nalazi u Zakonu o sportu. Lošije bi bilo da takve ili slične odredbe uopće nema. Međutim, to još uvijek ne znači da je zakonsko rješenje dovoljno dobro, kako glede biti, tako i glede nomotehničke razine. Načelno, prije detaljne analize, moguće su obje opcije i ona prema kojoj je to dobro riješeno i ona prema kojoj je to loše riješeno, uz čitav niz mogućih međuocjena.

28 Oleg Mandić, Sistem i interpretacija prava, Narodne novine, Zagreb, 1971. god., str. 201 i dalje. 


\section{Čl. 68. st. 1.-3. Zakona o sportu}

(1) Prenamijeniti površinu planiranu za javnu športsku građevinu, ukloniti ili prenamijeniti javnu športsku građevinu za namjene koje nisu športske djelatnosti može se samo uz suglasnost ministarstva na temelju prethodnog mišljenja športske zajednice na čijem se području nalazi športska građevina.

Odmah na početku se nameće pitanje što je to javna sportska građevina? Prema čl. 65., st. 2. Zakona o sportu javnim športskim građevinama smatraju se građevine koje su u vlasništvu Republike Hrvatske, odnosno u vlasništvu jedinica lokalne i područne (regionalne) samouprave i Grada Zagreba te se trajno koriste u izvođenju programa javnih potreba u športu. Prima facie izgleda kao da dvojbi niti ima niti ih može biti. Međutim, stvari se bitno mijenjaju vrlo brzo; dovoljno je uzeti u obzir samo dvorane koje su građene povodom Svjetskog rukometnog prvenstva 2009. u Osijeku, Poreču, Splitu,Varaždinu, Zadru i Zagrebu. Dogodilo se da je u to vrijeme potican model javno-privatnog partnerstva kao navodno spasonosan za financiranje, vrlo povoljan itd. Grad Osijek je odustao od tog modela, ali npr. Grad Split nije i postavlja se pitanje je li Spaladium arena u Splitu javna sportska građevina ili nije ako su njezini vlasnici po tom modelu privatna trgovačka društva i/ili banke (banke kao fiducijarni vlasnici), a Grad Split će postati vlasnik tek nakon isteka ugovorenog roka plaćanja, pod uvjetom da se plaćanje izvrši ${ }^{29}$ Drugo pitanje koje treba postaviti jest je li nešto sportska građevina ako se u njoj pretežito obavlja djelatnost koja nije sport (ne mislimo pri tome na razne poslovne prostore u sklopu građevine nego baš na ono što je centar svake dvorane - gledalište i prostor koji to gledalište okružuje), u prvom redu ona koncertna. Na primjeru samo dvije najveće dvorane (Split i Zagreb) jasno je da koncerata ima mnogo, a to što ih nema više možemo zahvaliti samo činjenici da ih se još više nije uspjelo organizirati. Da ima interesa bilo bi 365 koncerata godišnje, a sportaši bi (i to samo možda) dobili neke rane jutarnje termine. Istodobno, najbolji hrvatski rukometni klub (i jedan od najboljih na svijetu u posljednjih 20 godina) PPD Zagreb ne može dobiti termine za ovogodišnju Ligu prvaka zato jer ih nije u stanju platiti. ${ }^{30} \mathrm{Je}$ li onda prema Zakonu o sportu Spaladium arena u Splitu javna sportska građevina, je li uopće javna i je li uopće sportska - Zakon o sportu ne daje baš nikakvih elemenata za odgovor pa je jedino moguće zaključiti da je već $i$ zbog toga to loše zakonsko rješenje.

Loše je i što je propisana suglasnost ministarstva umjesto ministra, jer je tako omogućeno da bilo tko (ili barem bilo tko na višem položaju) na memorandumu ministarstva može izdati tu suglasnost.

29 Nažalost, cijeli taj projekt je u Splitu doživio katastrofu. I država i Grad Split obustavili su plaćanja privatnim partnerima odnosno bankama, kriveći jedni druge i u tijeku je stečajni postupak.

30 Jasno je da navijači nisu u mogućnosti platiti cijenu koju plaćaju oni koji dolaze na koncert, ali je uloga i značenje gledatelja i navijača bitno drukčija. Na ovom mjestu to ne možemo posebno elaborirati, ali prednost domaćeg terena je u bitnom vezana za broj navijača, a onda ih treba cijenom privlačiti, a ne tjerati. 
Nije moguće razumjeti (pa je već zato to loše rješenje) ni zašto se zahtijeva prethodno mišljenje (koje može biti i pozitivno i negativno, a moguća je i šutnja koju onda treba protumačiti) sportske zajednice, umjesto da se zahtijeva pozitivno mišljenje sportske zajednice (možda i uz neku kvalificiranu većinu kod glasovanja). Nije moguće razumjeti ni da nema baš ništa o pravilima postupka, umjesto da se vrlo precizno propiše cijeli postupak, svakako uključujući i što znači (pozitivno ili negativno mišljenje) eventualna šutnja sportske zajednice ${ }^{31}$ i potrebnu većinu, ali i tko daje mišljenje za sportsku zajednicu. ${ }^{32}$ Dodatno, nije isto je li za davanje mišljenja nadležna sportska zajednica grada, odnosno općine ili županijska sportska zajednica, a u zakonskom tekstu nema odrednice koja bi dala odgovor na tu dvojbu (o kojoj zajednici se radi). Koliko je to bitno, najbolje se vidi na primjeru malih općina, pa i gradova u kojima sportske zajednice ne funkcioniraju ni približno kao što je to slučaj u velikim gradovima.

Iz naprijed navedenoga vidi se da su na primjeru jednog jedinog zakonskog stavka stavljene četiri vrlo ozbiljne (barem po našem mišljenju) primjedbe, odnosno primjedbe na četiri zakonske formulacije. Još je gore to što se radi o primjedbama koje je lako otkloniti i, što je još značajnije, otklanjanje ne zahtijeva nikakav trošak.

(2) Suglasnost iz stavka 1. ovoga članka ne može se izdati:

- ako jedinica lokalne, odnosno regionalne (područne) samouprave nije planirala odgovarajuću zamjensku površinu $i$

- ako investitori prenamjene javne športske građevine, odnosno vlasnik javne športske građevine koja se uklanja ne preuzme obvezu i osigura uvjete izgradnje odgovarajuće zamjenske javne športske građevine.

(3) Iznimno od odredaba stavka 2. ovoga članka suglasnost se može dati samo ako se radi o građevini od posebnog interesa za Republiku Hrvatsku.

Formulacija „,ne može se izdati“ iz drugog stavka je jezički, pa posredno i nomotehnički, loša zato jer je očito da se misli da se ne smije izdati (a ne da se ne može kako je napisano), ali u praksi to ipak neće prouzročiti nikakve teškoće jer će se uvijek tumačiti kao „ne smije“. Iako je točno da je pravna nemogućnost (za razliku od stvarne koja ne ovisi o zakonodavcu odnosno normotvorcu) zabrana, ipak bi bilo i bolje i jasnije da stoji „ne smije se izdati“ umjesto „ne može se izdati“. Navedenoj formulaciji treba prigovoriti i to što ona ni na koji način ne obvezuje na izdavanje suglasnosti, ona se bavi samo situacijom kada se zabranjuje, kada se sprečava izdavanje suglasnosti. Ovo znači da je moguće zamisliti situaciju u kojoj je izdavanje suglasnosti diskrecijsko pravo ministarstva i kada su svi drugi uvjeti ispunjeni, što sigurno nije dobro rješenje. S druge strane, nema ni rješenja za slučaj onih sportskih sadržaja koji su planirani, eventualno i građeni s pretpostavkom bitno drukčijih demografskih kretanja nego što su ona

31 Dok u tekstu ne stoji da je nužno pozitivno mišljenje, ovo drugo nije bitno.

32 Iskustvo uči da, ako to ovisi samo o aktima i praksi te zajednice, to mišljenje na kraju može dati i neki službenik, umjesto najvišeg kolektivnog tijela te zajednice - skupštine. 
aktualna u kojima, nažalost, kao što imamo škole koje još uvijek rade u tri smjene, imamo i relativno nove zgrade čiji kapaciteti su ili potpuno ili gotovo potpuno neiskorišteni zato što djece, jednostavno, nema i kako sada stvari stoje, teško je za očekivati da će ih i biti. Dobro je i pohvalno štititi sport i sportaše, ali nije dobro skrbiti oko zamjenskih površina ako ih nitko neće koristiti.

Iz formulacije ,jedinica lokalne, odnosno regionalne (područne) samouprave“ u podstavku prvom stavka drugog proizlazi da je za nemogućnost primjene dovoljno da grad ili općina ili županija (jer riječ odnosno znači ili, drugim riječima ne zahtijeva se kumulacija), ,nije planirala“ (ma što to značilo), a a contrario ako jest planirala taj je uvjet za izdavanje suglasnosti ispunjen. Unatoč tome što planovi nižeg reda moraju biti usklađeni s onima višeg reda, ipak se u praksi često događa drukčije. Pri tome ponekad regionalna samouprava bez otpora promijeni svoj planski dokument na zahtjev općine ili grada, a ponekad ipak ne. Cak i kada postoji potpuna suglasnost, ukoliko postupak donošenja općinskog ili gradskog dokumenta započne tek kada se onaj na višoj razini potpuno dovrši, to znači kašnjenje koje se mjeri u mjesecima, ponekad i godinama, pa taj vremenski aspekt može potpuno promijeniti i kvalitetu i isplativost projekta. Na kraju, primjenom jezičke metode tumačenja, formulaciju ,nije planirala“ (a contrario ako jest planirala suglasnost se uz ostale uvjete može izdati) možda je moguće tumačiti i kao prijedlog - inicijativa npr. gradonačelnika upućena gradskom vijeću da se u određenom roku (npr. treća godina mandata) usvoji određeni planski dokument - zar to nije planiranje, odnosno kako tu mogućnost tumačenja isključiti? Iako smatramo kako je zakonodavac mislio na usvojene planske dokumente, teško je bilo kome objasniti zašto onda zakonodavac nije usvojio formulaciju iz koje bi nedvojbeno bilo da se radi o usvojenom i objavljenom planskom dokumentu koji je stupio na snagu. Situaciju dodatno komplicira zajednički stav Ustavnog suda Republike Hrvatske i Visokog upravnog suda Republike Hrvatske ${ }^{33}$ prema kojemu se u slučaju poništenja neke dozvole ponovljeni postupak glede planskih dokumenata vodi prema situaciji koja je postojala u vrijeme podnošenja zahtjeva - primijenjeno na ovu materiju izgleda kao da bi bilo udovoljeno zahtjevu da je nešto planirano iako je u međuvremenu taj planski dokument ukinut (što je sada nadležnost Visokog upravnog suda Republike Hrvatske).

Formulacija iz podstavka prvog stavka drugog ,odgovarajuća zamjenska površina $^{66}$ toliko je općenita da naprosto provocira nezakonitosti. Očito se radi o pravnom standardu ili kaučuk-normi koja ima svoje prednosti i nedostatke. Prednost je to što takva pravna norma može vrlo dugo trajati bez potrebe za promjenom, zato što ju je moguće vrlo različito tumačiti, ovisno o okolnostima koje postoje u konkretnom slučaju. Nedostatak je što takva preširoka pravna

33 Zaključci o pravnim shvaćanjima sa sjednice Imovinsko-pravnog odjela Upravnog suda Republike Hrvatske od 15. svibnja 2009. koja je odlučivala između različitih stavova Vrhovnog suda RH i Ustavnog suda RH - vidjeti web-stranicu Visokog upravnog suda RH. Naknadno je došlo do korekcije navedenoga pravnog shvaćanja na način da je 1. listopada 2013. god. zaključeno da se u postupcima prostornog uređenja primjenjuju podzakonski propisi koji su na snazi u vrijeme donošenja prvostupanjske odluke, ako zakonom ili podzakonskim propisom nije drugačije određeno. 
norma ne samo da omogućava, nego na određeni način čak i potencira pravnu nesigurnost i samovolju primjenjivača prava. Budući da ta (u značenju takva) formulacija ipak nije bila nužna teško ju je, pa i nemoguće, opravdati. Prima facie može djelovati kao da se radi o nečemu što je odgovarajuće po površini (u smislu kvadrata). Međutim, već pri samo malo ozbiljnijem promišljanju vidi se da je površina samo jedan (pa makar i početni, eventualno u nekim slučajevima i okolnostima i najvažniji) kriterij i da nikako ne može biti i jedini. Nije isto radi li se o pravilnom obliku nekretnine ili nepravilnom, radi li se o ravnoj površini ili ne, ima li ili nema raznog raslinja koje može biti i zaštićeno, bilo na samoj toj površini ili u tolikoj blizini da ograničenja djeluju i na tu površinu, ima li ili nema gledališta uopće ili s određenim svojstvima (koje je u nekim sportovima i razinama natjecanja uvjet za organizatora) itd. Treba dopustiti mogućnost da ponekad manja površina (u smislu metara kvadratnih) bude kompenzirana nečim drugim, pa i lokacijom, ali i opremom i drugim, ali pravila moraju biti jasna i jednostavna, svakako lako provediva i oslobođena mogućnosti (barem one velike) manipulacije. Bitan je i potencijal obje lokacije u smislu je li ili nije moguće, u slučaju potrebe, širenje. Pri svemu tome treba jasno konstatirati i da sve podatke glede neke sportske površine (od onih formalnih kao što su površina i smještaj, pa do onih koji su često vrlo malo formalni, u prvom redu tko i kako i koliko rabi tu površinu) daleko bolje poznaje lokalna zajednica od ministarstva na nacionalnoj razini. Druga je stvar što se iz raznih razloga podaci nažalost često ,friziraju“ i što je tu crimen najčešće baš na lokalnoj razini (bilo da se iz toga ostvaruju ili žele ostvariti neki materijalni probici, bilo da to služi samo u svrhu samohvale), ali i u tom slučaju onaj tko obavlja provjeru mora poći od tih podataka. Iz navedenoga proizlazi nužna koordinacija svih uključenih na ishođenju najboljeg rješenja. Kao i obično, dvojbe se najbolje pokazuju na konkretnom primjeru. Neupitno je da je stari stadion HNK Hajduk na kojemu se nogomet igrao do Mediteranskih igara 1979. god. i izgradnje novog stadiona u Poljudu apsolutno najatraktivnija parcela u Splitu. Neupitno je i da je u vlasništvu Grada Splita jer je tako presuđeno (baš u sporu s nogometnim klubom) od strane Vrhovnog suda Republike Hrvatske. Da je to sportska građevina, proizlazi iz toga što se tamo u kontinuitetu odvijaju aktivnosti dvaju sportskih klubova (ragbi klub Nada kojemu je prethodno oduzeto igralište koje su imali na drugoj lokaciji i istoimeni baseball-klub), uz minimalno sudjelovanje nesportskih djelatnosti ( $u$ prosincu se tu npr. u pravilu nađu zabavni ili cirkuski sadržaji). Iz navedenoga proizlazi da je to javna građevina, ali i da je sportska građevina. Na tržištu je jasno da je tržišna cijena te lokacije izuzetna, naravno pod uvjetom da tu bude nešto komercijalno (što je u konačnici i primjerenije strogom centru grada koji je pod zaštitom koju daje UNESCO). Sada je pitanje što bi to udovoljio zakonskim uvjetima kao odgovarajuća zamjenska površina, posebno kada se zna da odnos tržišne vrijednosti zemljišta može biti i $1: 10$ pa i više.

Izrazito je loše $\mathrm{i}$ to što ni jednom riječju nije određen, kao pravno relevantan, pravni status (izvan planske komponente) te površine (u prvom redu zemljišnoknjižno stanje). 
Formulacija iz stavka drugog podstavka drugog „,ne preuzme obvezu i osigura uvjete izgradnje odgovarajuće zamjenske javne športske građevine" djeluje kao da su je formulirali oni koji žive izvan ovog vremena i prostora, odnosno kao da su „prespavali“ mnogo toga lošeg što se događalo u novijoj hrvatskoj povijesti, pri čemu posebno mislimo na razdoblje pretvorbe društvenog vlasništva i privatizacije.

Upravo u velikoj mjeri zbog ,preuzimanja obveza“ na način koji ne uključuje gotovo nikakva (a posebno ne ona stvarnopravna koja djeluju erga omnes) osiguranja, nikakve ili gotovo nikakve penale i gotovo nikakve mogućnosti učinkovitog raskida ugovora koji počiva na takvom „preuzimanju obveze“, pretvorba i privatizacija su propali i izgleda da se na tom primjeru ništa nije naučilo, ponovno se propisuje obveza na način i uz osiguranja uslijed kojih to uopće nije obveza.

Posebno je pitanje što znači ,osigura uvjete izgradnje“. Ovisno o tumačenju, to može imati bitno različita značenja. Radi se o vrlo širokoj lepezi mogućih značenja, od onih minimalističkih zahtjeva prema kojima se radi samo o planskim odnosno urbanističkim aktima (ako je to, onda je dovoljna tzv. lokacijska informacija), ${ }^{34}$ ako se radi o još više zahtjeva, onda bi uz naprijed navedeno bilo potrebno i potpuno uređeno imovinskopravno stanje (u smislu vlasničkog lista 1/1), u maksimalističkom značenju (koje je jedino jamstvo da obveza neće ostati samo „na papiru“). Uz sve navedeno je nužna i osigurana financijska konstrukcija, svakako i uz više nego jasnu i više nego značajnu ugovornu kaznu koja će svakoga demotivirati u neispunjavanju preuzete obveze, svakako i uz osiguranje tipa bankovnog jamstva, hipoteke i sl.

34 Vidjeti čl. 36. Zakona o prostornom uređenju, NN 153/13, koji glasi:

(1) U svrhu upoznavanja s namjenom prostora i uvjetima provedbe zahvata u prostoru iz prostornih planova na određenom zemljištu, upravno tijelo na čijem se području nalazi zemljište, po zahtjevu zainteresirane osobe, izdaje lokacijsku informaciju u roku od osam dana od dana podnošenja zahtjeva.

(2) U zahtjevu za izdavanje lokacijske informacije navodi se ime, prezime i adresa, odnosno tvrtka i sjedište podnositelja zahtjeva te katastarska oznaka jednog ili više zemljišta (broj katastarske čestice i katastarska općina) za koja se traži izdavanje informacije.

(3) Lokacijska informacija se izdaje u pisanom obliku za zemljište navedeno u zahtjevu, a sadrži informaciju o:

1. prostornim planovima svih razina unutar čijeg obuhvata se nalazi zemljište

2. namjeni prostora i svim drugim uvjetima za provedbu zahvata u prostoru određenim, odnosno propisanim prostornim planovima svih razina

3. područjima u kojima je posebnim propisima propisan poseban režim korištenja prostora (kulturnim dobrima upisanim u Registar kulturnih dobara Republike Hrvatske i dr.), ako se zemljište nalazi na takvom području

4. obvezi donošenja urbanističkog plana uređenja, ako se zemljište nalazi na području za koje je takva obveza propisana ovim Zakonom

5. prostornim planovima i/ili njihovim izmjenama i dopunama, čija je izrada i donošenje u tijeku

6. mjestima na kojima se može izvršiti uvid u prostorne planove i vrijeme kada se to može učiniti.

(4) Lokacijska informacija se na zahtjev stranke dostavlja elektroničkim putem.

(5) Lokacijska informacija sadrži i napomenu da se na temelju iste ne može pristupiti provedbi zahvata u prostoru niti izradi projekata propisanih posebnim zakonom.

(6) Lokacijska informacija nije upravni akt. 
Dvojbeno je i što znači ,odgovarajuća zamjenska javna športska građevina“. Ključno i najvažnije je što je nejasno što znači pojam odgovarajuća o čemu smo već naprijed pisali, ali nije beznačajno ni to što je u slučajevima ako što je npr. Spaladium arena u Splitu stvarno nejasno je li to javna ili nejavna (radi javnoprivatnog partnerstva), sportska ili nesportska (jer gotovo da ima više koncerata i sličnih događanja nego sporta, a samo da ima interesa, djeluje kao da sporta ne bi ni bilo).

(3) Iznimno od odredaba stavka 2. ovoga članka suglasnost se može dati samo ako se radi o građevini od posebnog interesa za Republiku Hrvatsku.

Nitko odgovoran neće dovoditi u pitanje ništa što je od posebnog interesa za Republiku Hrvatsku. To nije sporno i vjerujemo da neće ni biti sporno. Međutim, nije jasno zašto Republika Hrvatska, kada se već radi o njezinom posebnom interesu, ne preuzme obvezu osigurati odgovarajući zamjenski prostor. Država to može ako hoće. Pitanje je samo zašto zakonska formulacija djeluje kao da nikakve obveze nema i zašto se sve onda ne prepusti postupku prema pravilima o izvlaštenju, bez specijalnih normi u Zakonu o sportu.

\section{IV.2. PRIJEDLOZI DE LEGE FERENDA}

Iz naprijed navedenoga proizlazi kako postoje primjedbe glede svakog dijela članka 68. Zakona o sportu koji uređuje ovu materiju. Manjim dijelom su to stvari koje spadaju u nomotehniku, većim dijelom su to problemi koji se tiču biti stvari.

Sam institut i deklarirana želja pomoći sportu na način da se načelno zabranjuje prenamjena (osim u slučaju ispunjenja strogih zakonom propisanih uvjeta) nisu sporni. Ipak, to je toliko loše izvedeno da je vrlo upitno najprije zašto je to tako, a nakon toga $\mathrm{i}$ je li postojeće zakonsko rješenje jamči ozbiljnu razinu učinkovite zaštite.

Svakako je rješenje u bitnom korigirati - popraviti zakonsko rješenje na način koji će jamčiti zaštitu sporta, neovisno o bilo čijoj pojedinačnoj dobroj ili lošoj namjeri. Bez želje pripisivati sebi neko ekskluzivno pravo, ni kritizirati postojeće rješenje ni nuditi potpuno novo, sigurni smo da je ovo postojeće rješenje školski primjer loše odrađenog posla stvaratelja norme, a ostaje dvojba zašto je tako i zašto gotovo uvijek sport i sportaši moraju biti na strani koja trpi štetu.

\section{ZAKLJUČAK}

Gotovo svi smo na ovaj ili onaj način uključeni u sport, od statusa prijatelja ili ljubitelja sporta, preko navijača pa do sportaša, trenera i dužnosnika u sportu. Pri tome pravi broj dobijemo kada uzmemo u obzir da su čak i oni koji sada nemaju nikakve veze sa sportom vjerojatno tu vezu imali ili će je pak imati profuturo. U konačnici, sport je putem sati tjelesnog odgoja i dio sustava obrazovanja, a da je standard malo veći, vjerojatno bi tjelovježba bila i dio radnog procesa, ne iz razloga altruizma nego zato što je dokazano da pravilno određena i dozirana tjelovježba 
povećava radne učinke radnika, posebno na poslovima koji inače ne zahtijevaju značajan fizički angažman. Poznati su i podaci koliko ulaganja u sport štede na troškovima zdravstva u skladu s poznatom izrekom MENS SANA IN CORPORE SANO. Poznato je i koliko je sportaša aktivno sudjelovalo na raznim razinama vlasti gdje su očito imali prigodu učiniti mnogo za sport. ${ }^{35}$ Nitko ne osporava ni da je sport najbolji hrvatski izvozni proizvod, najbolji hrvatski ambasador, najčešći razlog velikog hrvatskog ponosa u situacijama uspjeha koji su stvarno česti ${ }^{36}$ (ali i tuge u slučaju poraza, pa čak i kada je to npr. poraz u finalu najvećeg turnira na svijetu, što objektivno znači biti drugi na svijetu, što je prema bilo kojem kriteriju izniman uspjeh). ${ }^{37}$

Polazeći od naprijed navedenoga, izgleda potpuno normalnim očekivati da sport u hrvatskoj zbilji nikada ne bude oštećen, dakle da uvijek u svakom smislu dobije ono što zaslužuje. Nažalost, to što je normalno za očekivati baš se nikada ne događa i položaj sporta u cjelini je sve lošiji. Sve je manje novca, mediji sve manje daju prostor onom pozitivnom (ali zato je suprotno kod prikazivanja negativnosti), urbanizacija otima prirodan prostor sportu, novčane ponude iz inozemstva dovode do toga da cijele obitelji odlaze u inozemstvo prateći nekog npr. malog nogometaša... Ako na sve naprijed navedeno ne možemo utjecati (bilo uopće bilo značajno) jer smo siromašni i jer smo objektivno prisiljeni „igrati“" po globalnim pravilima (slobodno tržište i sl.), onda nije jasno kako i zašto nismo u stanju u 25 godina imati ako ne perfektan, onda barem dobar zakon o sportu. Koliko je izuzetno loše ono što imamo pokazuje i ovaj tekst i analiza koju u njemu dajemo u odnosu na samo jedan članak (čl. 68.). Do sličnog zaključka dovela bi i analiza kojeg drugog članka, a to je nedopustivo i ne može se ničim opravdati, te nema veze s raspoloživim novčanim sredstvima.

35 Primjeri iz Hrvatskog sabora su npr. Perica Bukić (vaterpolo), Danira Nakić (košarka), Damir Škaro (boks), iz Vlade Republike Hrvatske Petar Skansi (košarka), Tomislav Paškvalin (vaterpolo) - s obzirom na to da ne postoji posebno ministarstvo sporta, oni su kao pomoćnici za sport praktično bili (Skansi) odnosno sada je u položaju ministra sporta, lokalna razina Željko Jerkov u jednom punom mandatu predsjednik Gradskog vijeća Grada Splita, Goran Pauk dugogodišnji župan Šibensko-kninske županije itd.

36 Sjetimo se samo Gorana Ivaniševića i Janice Kostelić i Blanke Vlašić i Sandre Perković i Marina Čilića, da spomenemo samo najpoznatije iz pojedinačnih sportova, Tonija Kukoča, Dina Rađu, Dražena Petrovića (košarka), Ivana Balića i Domagoja Duvnjaka (rukomet), Luku Modrića (nogomet), Pericu Bukića i Milivoja Bebića (vaterpolo)...

37 Goranu Ivaniševiću to se dogodilo čak tri puta u Wimbledonu. 


\section{ONE SPECIFIC RESTRICTION OF PROPERTY RIGHTS (CONVERSION SURFACE, REMOVAL OR CONVERSION OF SPORT FACILITIES)}

In this article, the author deals with the restriction of property right as well-known legal institution, but on a specific example of a particular limitation of the Sports Act. It is about the prohibition of conversion of area, removal or conversion of public sports facilities. With presenting a series of elements of limitations at all, the text is presenting a series objections to the specific legal solution, remarks that practically cancel a good will of the legislator that in this way helps the sport.

Key words: property right, limitation, real estate, constitutionality 